\title{
The Health Belief Model in Prevention Pesticide Toxicity
}

\author{
Eka L. Mahyuni ${ }^{1} \&$ Urip Harahap ${ }^{2}$ \\ ${ }^{1}$ Department of Safety and Health, Faculty of Public Health, Universitas Sumatera Utara, Medan, Indonesia \\ ${ }^{2}$ Department of Pharmaceutical Chemistry, Faculty of Pharmacy, Universitas Sumatera Utara, Medan, Indonesia \\ Correspondence: Eka L. Mahyuni, Department of Safety and Health, Faculty of Public Health, Universitas \\ Sumatera Utara, Medan, 20155, Indonesia. Tel: 62-813-7628-7171. E-mail: eka.lestari@usu.ac.id; \\ e79mahyuni@gmail.com
}

Received: March 25, 2020 Accepted: April 17, 2020 Online Published: April 29, 2020

doi:10.5539/gjhs.v12n6p135 URL: https://doi.org/10.5539/gjhs.v12n6p135

\begin{abstract}
Various efforts have been made to reduce pesticide toxicity, but the level of community participation is still quite low. This study aims to analyze the health belief of Karo's farmer in pesticide toxicity prevention. The sample used the snowball sampling technique and reach 55 participants. Data were collected by in-depth interviews, FGD, and analyzed in qualitative used thematic analysis. The results found that farmers knew the hazard and effects of pesticides, but they ignored all of prevention. They continue to survive using pesticides cause indirect effects and temporary form of pesticides. They will refer to health services if it was eaten or inhaled, with acute effects and this is very rare. These perceived of farmer showed no benefit to prevent the pesticide. Overall, the farmer will participate in the health programmed if it has the real object and has significant changes to the economic and welfare of farmers. It concluded that the model of health belief could be changing the health behavior in pesticide use influences by the pesticide hazard, fluctuating of market price and horticulture products in bigger demand, traditional medicine habit, and government assurance to farmers.
\end{abstract}

Keywords: farmers, health belief, pesticides, prevention, behavior

\section{Introduction}

Increased of pesticide use as an intensification program for agricultural development will be followed by increased exposure and farmer's toxicity (Sukmawati \& Maharani IP, 2004). Inappropriate use of pesticides is harmful to farmer's health and consumers, non-target microorganisms and have an impact to environmental pollution such as soil and water pollution due to the use of fertilizers and pesticides in Kendal; organochlorine pesticide pollution in Jakarta Bay, and Klabat Bay in Bangka Island and the presence of organochlorine pesticide residues of carrots in Karo District (Karyadi, 2008; Khozanah, 2010; Munawir, 2005; Sinulingga, 2006).

Pesticide toxicity is the world problem and increase in every year both with acute and chronic effects (World Health Organization, 2017). In April-June 2017 period, the incidence of pesticide toxicity occurred in North Sumatra, allegedly because the source of water in the residents' homes was polluted by agricultural pesticides. This incident resulted in 120 victims without any deaths (Sentra Informasi Keracunan Nasional, 2017). Poisoning cases also often occur in Karo District and are spread in several areas ranging from an average of $55.26 \%$ to $91.25 \%$ (Dinas Kesehatan Kabupaten Karo, 2008). Acute toxicity also often occurs due to the ingestion of herbicides, pesticides, Gramaxon, and Roundup (Rumah Sakit Umum Kabanjahe, 2018). It means the risk of toxicity is very high in pesticides used by farmers, and the tendency to experience chronic toxicity was potentially high in the Karo Regency.

Chronic toxicity more difficult to detect because it is not directed to show the specific symptoms and signs. However, chronic toxicity in a long time causes the health problems that are often associated with pesticide use like eye and skin irritation, cancer, miscarriage, defects in infants, as well as nerve, liver, kidney, and respiratory problems. Based on literature studies, the effects of pesticide exposure caused multiple myeloma, sarcoma, prostate and pancreatic cancer, uterine cancer, pancreas, breast cancer, neurobehavioral, and Hodgkin (Alavanja, Hoppin, \& Kamel, 2004; Arcury \& Quandt, 2003; Deborah, 2006; Engel et al., 2005). The other symptoms such as pupils or iris slits narrowing that made the vision becomes blurred, watery eyes, foaming mouth, headaches, dizziness, shock, rapid heartbeat, nausea, vomiting, stomach cramps, diarrhea, breathing difficulties, paralyzed and faint (Yuantari, 2011; Yuantari, Widianarko, \& Sunoko, 2015). 
The highest pesticide use in horticulture considering the short plant and pest-prone are followed by the increased risk of pesticide poisoning. Several programs have been launched to create a healthy agricultural sector. Starting from the transition of agriculture intensification towards organic systems, the transition of plant-based or bio-pesticide technologies, even the socialization and extension of methods for using pesticides and empowering farming communities to achieve health agriculture (Arfan \& Araswaty, 2018; Kementerian Kesehatan Republik Indonesia, 2018; Kurniasari, Hartati, \& Riwayati, 2009; Moekasan \& Prabaningrum, 2011; Setiawan, Redjeki, \& Nasution, 2017). However, farmers still do not care and choose to show inappropriate work methods. Farmers also ignore the complaints that are felt while using pesticides (Mahyuni, 2015; Mahyuni, Yustina, \& Sudaryati, 2017). This discrepancy assumed due to the perception of farmers who didn't understand and believe the benefits of the programs provided. The health risk of farmers never cared for and no special attention. But in reality, the community has a unique perception in responding to government programs with toxicity events that pose risks to farmers' work while using pesticides.

The health belief model recognizes an individual perceived susceptibility of toxicity, perceived severity of toxicity, perceived benefits of certain behaviors in reducing toxicity, and perceived barriers to prevention action. These perceived could apply to knowledge, health beliefs and compliance in pesticide toxicity (Rosenstock, 1974; Thalacker, 2010; Glanz, Rimer, \& Viswanath, 2014; Lewis G, H., Sheringham, J., Kalim, K., \& Crayford, 2014; Onoruoiza et al., 2015). Various studies have shown that the health belief model is more likely to emphasize health education, the development of community behavior, and culture in responding to an intervention effort. In this case the community adopts all interventions as health innovation that plays a role in behavior change. The health belief model also plays a role in exploring every determinant of a health problem including the pesticide toxicity problems (Armstrong, Anderson, Le, \& Nguyen, 2009; Baghianimoghadam et al., 2013; Brown, Ottney, \& Nguyen, 2011; Chen et al., 2011; Emmanuel, 2015; James, Pobee, Oxidine, Brown, \& Joshi, 2012; Melzner, Heinze, \& Fritsch, 2014)

This study aims to apply the concept of the health belief model to assess the behavior of pesticide prevention among farmers. This study assesses how the community belief in health efforts to reducing the risk of pesticide toxicity. This theory seeks to explain and predict the health-related behaviors given from certain patterns of beliefs about the recommended health behavior and health problems to prevent or control (Kholid, 2015; Machfoedz, 2006; Notoatmodjo, 2003). The health belief model is used as an effort to explain broadly the failure of community participation in disease prevention or detection programs and often considered as the main framework in behavior related to human health starting from people's considerations about health (Maulana, 2007).

\section{Method}

This research was conducted in Karo District from March until November 2019. The sample size was determined by the snowball sampling method of the horticultural farmer's population and it reach into 55 participants. The participant is the farmers who used pesticides as daily activities. The variables observed were the behavior of pesticide toxicity prevention, namely perceived susceptibility, perceived severity, cues to action, perceived benefits, perceived barriers, and community behavior in efforts to prevent pesticide poisoning. The health belief model has a role in exploring the causes of behavior to make efforts due to pesticide use. These perceptions will be categorized into three concepts, namely perceived threat to the risks that will arise; the concept of the advantages and disadvantages of the behavior in deciding whether or not to take preventative actions and the concept of behaving healthily includes information, promotion and advice related to pesticide toxicity.

It is an explanatory research with a mixed-method approach, by exploring, analyzing, and found in continuously all the processes as the reason for a health phenomenon in pesticide toxicity. Ethical clearance considering the treatment of this study that declares by ethics committee with number 1952/II/SP/2019. The data carried out by in-depth interviews technique and meet in Focus Group Discussion (FGD) to discuss anything that related to understanding the concept of community belief in health efforts to prevent the risk of pesticide toxicity. The data will be extracted and analyzed qualitatively using thematic analysis techniques. Each data obtained will give meaning to each variable or factor that refers to the Health Belief Model so that a model to be the base of farmer's behavior changing in efforts to prevent pesticide toxicity based on Rosenstock's theory (1974) as a research framework: 


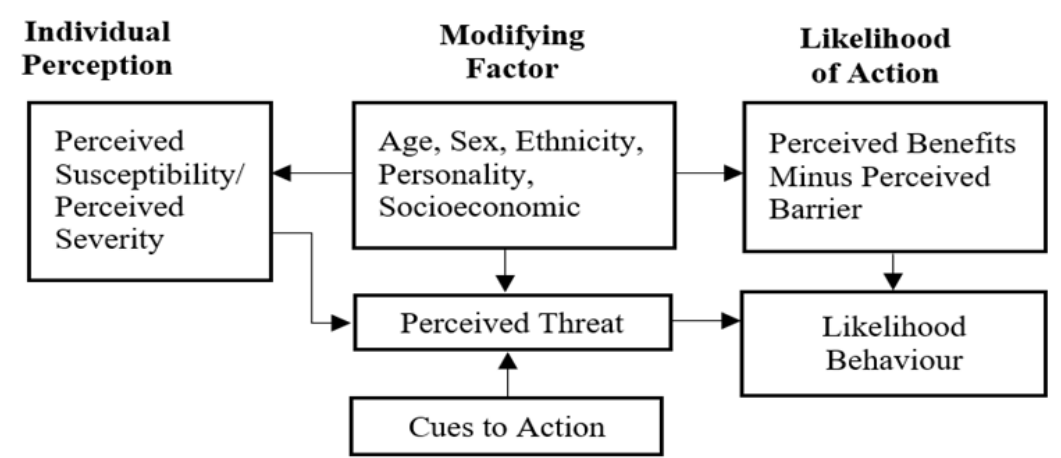

Figure 1. Research Framework Based on The Health Belief Model (Rosenstock, 1974)

\section{Result and Discussion}

Karo District is the urban that dominate by agriculture and the highest of pesticide used. It looks so many interesting behavior in pesticides used. The individual character of farmers in pesticide use shown in Table 1.

Table 1. Individual Characteristic of Karo's Farmers

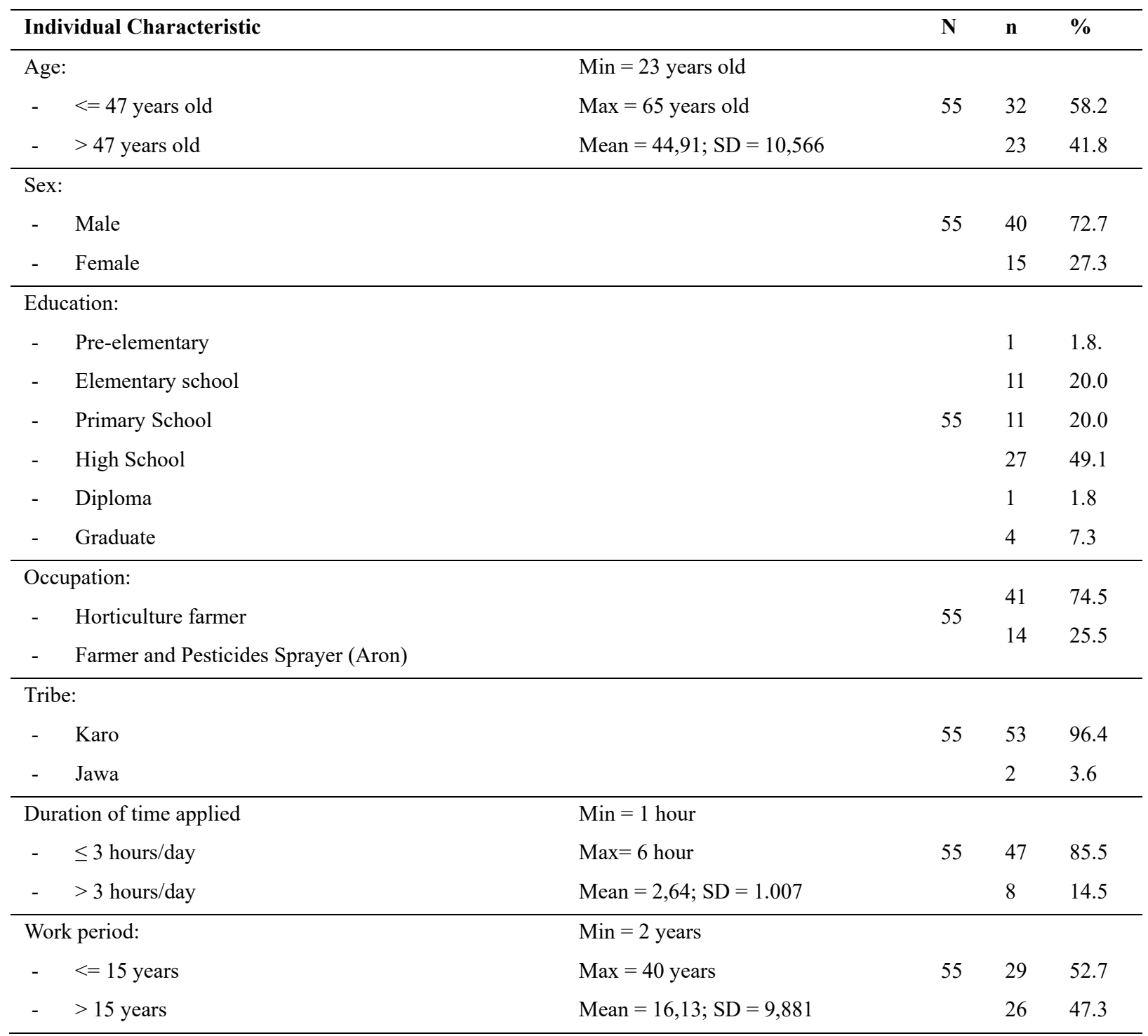




\begin{tabular}{|c|c|c|c|c|}
\hline \multicolumn{5}{|c|}{ Pesticide type } \\
\hline - & Insecticide & 55 & 55 & 100 \\
\hline - & Fungicide & & 55 & 100 \\
\hline \multicolumn{5}{|c|}{ Class of toxification } \\
\hline - & Low acute toxicity & & 10 & 18.2 \\
\hline - & Moderate acute toxicity & 55 & 38 & 69.1 \\
\hline - & Acute toxicity & & 7 & 12.7 \\
\hline \multicolumn{5}{|c|}{ Health effect of pesticide } \\
\hline - & Eyes irritation & & 37 & 67.3 \\
\hline - & Skin rash & & 42 & 76.4 \\
\hline - & Nausea & 55 & 12 & 21.8 \\
\hline - & Respiratory disorders & & 30 & 54.5 \\
\hline - & Dizzy and headache & & 45 & 81.8 \\
\hline - & Muscle spasms & & 55 & 100 \\
\hline
\end{tabular}

This research location is dominated by the Karo tribe (96.4\%) and generally engaged in horticulture. Farmers not only act as owners of the fields but also act as pesticide sprayers that called "aron" (25.5\%). As many as $47.3 \%$ of farmers have used pesticides for a long time since childhood (see Table 1). It means the farmers have a long interaction with chemicals because Karo District still uses synthetic pesticides to increase agricultural production. In recent years, Karo District has been socialized by natural pesticides, but it has not been applied in this village. Several efforts to improve farmers' health have been carried out, but farmers are more interested in technology programs to increase production yields. Farmers never care about all health programs because it only in the socialization of personal protection use form.

Farmers didn't want to use the personal protection cause the uncomfortable and giving long duration of work. The farmer feels difficult when using personal protection cause it makes the work was not effective. Besides that, personal protection is generally given at certain times and not provided as a whole.

“...here, the program is not only counseling with masks but buying the masks by myself, but it's also difficult to use it ... so it works slowly, for example, boots, uncomfortable, it makes we can't feel the ground that we step on. Even if we use masks, it is hard to breathe" (Derianto, 43 years old).

Average farmers do not use personal protection and only $8 \%$ of farmers use it when applying pesticides. As a result, farmers are often exposed to pesticides and it is the risk that causing acute or chronic poisoning. Personal protective equipment as an intervention to minimize exposure of pesticide among farmer and it have to use before, during, and after pesticide application. The perceived usefulness of PPE driven by unavailability, high price, lack of use by other farmers, and ignorance of PPE in extension training. The misuse of protective equipment results in health risks among farmers related to the port of entry of exposure like dermal, inhalation, or oral. All port of the entry of exposure could be given the effect of health symptoms or toxicity signs (Bondori, Bagheri, Damalas, \& Allahyari, 2018; Feola, Gallati, \& Binder, 2012; Lu, 2006; Macfarlane, Carey, Keegel, El-Zaemay, \& Fritschi, 2013; Minaka, Sawitri, \& Wirawan, 2016; Sharifzadeh, Damalas, \& Abdollahzadeh, 2017; Yarpuz-Bozdogan, 2018).

The first concept of health belief is related to perceived threats to the risks that will arise. In pesticide use, especially horticultural farmers in this village are unique. According to the farmer's perception that the pesticides used didn't give impact considering they have been using it for decades. Farmers have the perception that they do not need to protect themselves because they are used to it. Farmers do not feel threatened with the risk of pesticide poisoning which triggers this perception because of the effects of chronic and disappearing pesticides. Only 14 farmers $(25.5 \%)$ who feel it has an immediate effect while using pesticides with symptoms such as dizziness, nausea, and fatigue. The majority of the toxic effects affecting farmers were felt 30 minutes after spraying pesticides, as many as 29 people from 55 participating farmers (52.7\%). Only the effects on the skin felt for a long time by farmers such as burning and redness on the skin and even itching on the skin. The odor effect emitted from pesticides that are often inhaled by farmers is also ignored by farmers because dizziness or headaches can be relieved by rest (5.5\%). Even in their application farmers continue to spray (7.3\%). Farmers often admit that at the 
beginning, the effects of symptoms are often felt, but it becomes accustomed cause the long period of using pesticides. It is assumed the experience of chemical resistance and chronic toxicity due to the pesticide use. In basically, farmers know the dangers of the pesticide used but they did not understand the direct effects on body parts, due to the temporary nature of the poison. While the toxins used will accumulate in the body and act as triggers for degenerative diseases (Guvenc, Akyuz, \& Açikel, 2011; Lennon, 2005; Lu, 2006; Solhi, Zadeh, Seraj, \& Zadeh, 2010).

Pesticide exposure is often experienced such as splashing in eyes, skin of hands, and feet. This is indicated by complaints felt by farmers while using pesticides such as dizziness, shortness of breath, cold sweating, nausea, vomiting, and fatigue. This symptom shows mild symptoms but felt in daily (98.2\%). The accumulation of these symptoms will potentially cause cancer and other health problems. Based on observations, farmers also have the habit of blowing/sucking the hose of the spraying hose to lure the pesticide mixture out and ready to be sprayed. Besides, there are times when a farmer's behavior can stir the chemical mixture directly by hand without using personal protective equipment. In general, the method of using pesticides is not by established procedures. This phenomenon shows the unsafe behavior of farmers while using pesticides. As a result, the risk of pesticide poisoning is very potential that can be experienced by farmers in Karo. It can be assumed that even if the effect is mild, it is also possible that chronic accumulation of symptoms can trigger acute and severe health problems.

The second concept explains the advantages and disadvantages of the behavior of farmers in deciding whether or not to take action related to the medical world. Based on the results of research farmers are more likely to do independent treatment than having to use available health facilities. Farmers generally take simple actions to reduce the toxic effects that are felt by using pesticides. Some things that are done such as resting sitting, drinking Karo herbal, sleeping rest, and so on. So that although farmers feel mild symptoms due to exposure to pesticides, in general farmers do not consult a doctor $(92.7 \%)$.

"Never see a doctor, if you have a headache, take a rest, sit for a while, or sleep. So why do you pay to the doctor much longer, better the money to buy food? While drinking, the dizziness usually goes away ... It's just getting tired ... often because of the smell that makes me dizzy" (Linda Tarigan, 43 years old).

It can be concluded that the effects or symptoms of toxicity felt by farmers are not permanent but is temporary. This tends to make farmers ignore the other impacts where unwitting exposure to pesticides that enter will settle into the body's system, causing chronic poisoning. This attitude shows that farmers feel no advantage in becoming a health program because they are not able to increase the yields managed by farmers. In this case it is necessary to study social cognitive and ecological models. Culture also has a big role in increasing community participation (Glanz et al., 2014; James et al., 2012; Kholid, 2015; Lennon, 2005; O’Connor, Martin, Weeks, \& Ong, 2014).

The third concept is a guide to healthy behavior, which is information from outside or advice on pesticide toxicity issues, such as mass media, health promotion, and advice from other people or friends related to pesticide toxicity. Based on the analysis of two previous concepts, the majority of farmers are still reluctant to take preventative measures because farmers' perceptions state there are no advantages and no direct contribution to the effects or health potential of farmers. But the awareness and attention of farmers to poisons is quite high. $100 \%$ of farmers know the dangers of pesticides. This perception increases when the pesticide is swallowed or eaten so that it gives an acute or immediate effect which urges farmers to refer to the hospital. However, due to careful use farmers consider it harmless due to the chronic effects experienced. Farmers in Karo consider it a normal thing and are accepted with a heart breach. Because farmers also recognize that pesticides are a necessity that greatly helps their production yields. So that if the action of an intervention done to sensitize farmers sustainably. One effort that can be done through the concept of health promotion related to the prevention of poisoning. From this concept, the Karo farming community still applies a simple promotion pattern. Generally farmers convey information by chatting in coffee shops. From the conversation carried out by farmers can tell all the problems they experienced. Starting from crop failure, lack of production, health, and other problem topics. The habit of gathering at the coffee shop is done while drinking tea or coffee to establish kinship for the people of Karo. In this case the emotional role in responding to an intervention is very instrumental in increasing confidence in the effects of poisoning on health. For this reason, the role of psychosocial theory needs to be upheld in understanding the complexity of the problem of poisoning due to pesticides. The farmers also have the wayward character where their perceived is the fell healthy and resistance with the pesticide effect even it exposure in a long time (chronic) (Becker, 1974; Conner, 2015; Harvey \& Lawson, 2009; Strecher \& Rosenstock, 1997). 
Table 2. Health Belief Model in Pesticide Toxicity

\begin{tabular}{ll}
\hline Concept & Application \\
\hline Perceived susceptibility & Farmer feel the effect was no danger and could be prevented myself \\
Perceived severity & The effect could control by good rest and drink of Tawar Karo \\
Perceived benefit & The prevention giving the benefit if it continuing and well informed to community \\
Perceived barriers & The relation between government and community have to change \\
Cues to action & Need well organize by agent of change and act in social movement or engagement \\
Self-efficacy & Collaboration with government and stakeholder to develop intervention and state the \\
& assurance for farmer's health \\
\hline
\end{tabular}

The behavior to prevent the risk of toxicity due to pesticides use is done through the delivery of messages and direct communication. Awareness of preventing the risk of toxicity becomes a very hot topic. Based on the FGD results conducted with the community, to promote a risk prevention program for pesticide toxicity, farmers assume that prevention methods that are appropriate to the culture of farming in Karo are through regular meetings and meetings, followed by promotion and the need for strict policies related to pesticides use. So that people could participate in prevention programs also need support from the government or related agencies, especially in controlling market demand for agricultural products. With regular support and supervision, farmers will feel the government guarantee to maintain the effects of poisoning due to pesticide use that has been neglected. The government could increase the cultivation technique like educated and trained farmers on how to use pesticides or by the regulation where all about pesticides could be taken to ensure the balance of business and human health. On the other hand, the government needs to prepare to be a donation of pesticide prevention in daily which is integrated into public policy and builds the farmer's organization in government bodies. All programs need the cooperation is strongly associated with all related parts to increase the health promotion actions such as pesticide toxicity intervention (Aktar, Sengupta, \& Chowdhury, 2009; Haby, Chapman, Clark, \& Galvão, 2016; Mahyuni et al., 2017; Osang, Lampus, \& Wuntu, 2016; Rustia, Wispriyono, Susanna et al., 2010; Simonsen-Rehn, Laamanen, Sundell, Brommels, \& Suominen, 2009; Syahyuti, 2016; United Nations Children's Fund (UNICEF), 2018). The concept of farmers' trust in health in the use of pesticides can be seen in the following Figure 2:

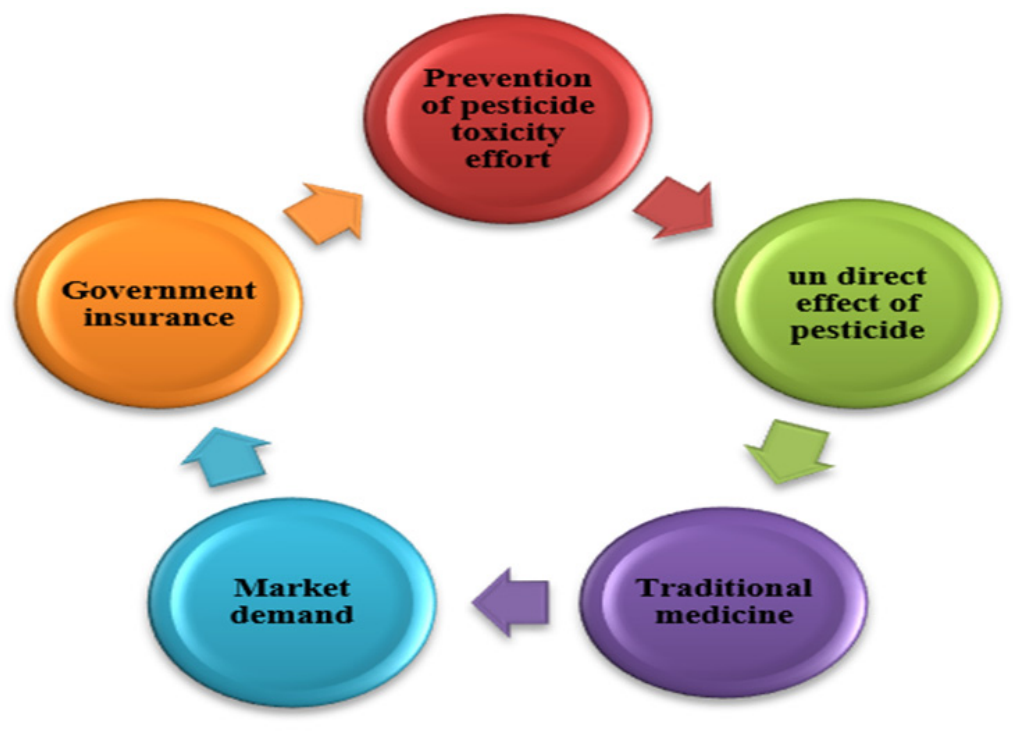

Figure 2. Farmer's Health Belief Model

\section{Conclusion}

The model of health belief could change the health behavior in pesticide use that carried out comprehensively by develop the toxicity promotion. The model of health belief in pesticide toxicity prevention influences by the pesticide hazard, market price, and horticulture products in bigger demand, traditional medicine habit, and 
government assurance to farmers.

\section{Acknowledgements}

We said thanks for all farmer that giving contribution in this research. All of this could be recommended from the participation of Mr. Dinis Karo-Karo as a leader of the village that coordinate with Mr. Timur Tarigan and Mr. Japet Tarigan that make the research easier with the best collaboration with all farmer community in Karo District. Big thanks we giving for Lembaga Penelitian USU that funding this research in the best arrangement in the research program of TALENTA with contract number: 4167/UN5.1.R/PPM/2019, date: 01 April 2019.

\section{Competing Interests Statement}

The authors declare that there are no competing or potential conflicts of interest.

\section{References}

Aktar, W., Sengupta, D., \& Chowdhury, A. (2009). Impact of pesticides use in agriculture: Their benefits and hazards. Interdisciplinary Toxicology, 2(1), 1-12. https://doi.org/10.2478/v10102-009-0001-7

Alavanja, M. C. R., Hoppin, J. A., \& Kamel, F. (2004). Health Effects of Chronic Pesticide Exposure: Cancer and Neurotoxicity. Annual Review of Public Health, 25(1), 155-197. https://doi.org/10.1146/annurev.publhealth.25.101802.123020

Arcury, T. A., \& Quandt, S. A. (2003). Pesticides at work and at home: Exposure of migrant farmworkers. Lancet, 362(9400), 2021. https://doi.org/10.1016/S0140-6736(03)15027-1

Arfan, \& Araswaty. (2018). Pkm Pemberdayaan Petani Bawang Merah Lokal Palu Melalui Penerapan Model SLPHT di Desa Wombo Kecamatan Tanantovea Kab. Donggala Provinsi Sulawesi Tengah. Jurnal Pengabdian Masyarakat, 1(10), 14-19. https://doi.org/10.31970/abditani.v1i0.8

Armstrong, S. N., Anderson, M., Le, E. T., \& Nguyen, L. H. (2009). Application of the Health Belief Model to Bariatric Surgery. Gastroenterology Nursing. https://doi.org/10.1097/SGA.0b013e3181a7cf5a

Baghianimoghadam, M. H., Shogafard, G., Sanati, H. R., Baghianimoghadam, B., Mazloomy, S. S., \& Askarshahi, M. (2013). Application of the health belief model in promotion of self-care in heart failure patients. Acta Medica Iranica.

Becker, M. H. (1974). The health belief model and personal health behavior. Health Education Monographs. https://doi.org/10.1177/109019817400200407

Bondori, A., Bagheri, A., Damalas, C. A., \& Allahyari, M. S. (2018). Use of personal protective equipment towards pesticide exposure: Farmers' attitudes and determinants of behavior. Science of the Total Environment, 639(15), 1156-1163. https://doi.org/10.1016/j.scitotenv.2018.05.203

Brown, W., Ottney, A., \& Nguyen, S. (2011). Breaking the barrier: The Health Belief Model and patient perceptions regarding contraception. Contraception. https://doi.org/10.1016/j.contraception.2010.09.010

Chen, M. F., Wang, R. H., Schneider, J. K., Tsai, C. T., Dah-Shyong Jiang, D., Hung, M. N., \& Lin, L. J. (2011). Using the health belief model to understand caregiver factors influencing childhood influenza vaccinations. Journal of Community Health Nursing. https://doi.org/10.1080/07370016.2011.539087

Conner, M. (2015). Health Behaviors. In International Encyclopedia of the Social \& Behavioral Sciences: Second Edition. https://doi.org/10.1016/B978-0-08-097086-8.14154-6

Deborah, R. (2006). Are pests the Problem or Pesticides. Biology Journal, 28(1), 6-7.

Dinas Kesehatan Kabupaten Karo. (2008). Data Pemeriksaan Cholinesterase Pengguna Pestisida Kabupaten Karo tahun 2008. Subdin P2P \& PL Dinas Kesehatan Kabupaten Karo.

Emmanuel, A. (2015). A Literature Review of the Factors That Influence Breastfeeding: An Application of the Health Belief Model. International Journal of Nursing and Health Science.

Engel, L. S., Hill, D. A., Hoppin, J. A., Lubin, J. H., Lynch, C. F., Pierce, J., ... Alavanja, M. C. (2005). Pesticide use and breast cancer risk among farmers' wives in the agricultural health study. American Journal of Epidemiology, 161(2), 121-135. https://doi.org/10.1093/aje/kwi022

Feola, G., Gallati, J. A., \& Binder, C. R. (2012). Exploring behavioural change through an agent-oriented system dynamics model: The use of personal protective equipment among pesticide applicators in Colombia. System Dynamics Review, 28(1), 69-93. https://doi.org/10.1002/sdr.469

Glanz, K., Rimer, B. K., \& Viswanath, K. (2014). Health Behavior: Theory, Research, and Practice. Health 
Behavior : Theory, Research, and Practice. https://doi.org/10.7326/0003-4819-116-4-350_1

Guvenc, G., Akyuz, A., \& Açikel, C. H. (2011). Health Belief Model Scale for Cervical Cancer and Pap Smear Test: Psychometric testing. Journal of Advanced Nursing. https://doi.org/10.1111/j.1365-2648.2010.05450.x

Haby, M. M., Chapman, E., Clark, R., \& Galvão, L. A. C. (2016). Interventions that facilitate sustainable jobs and have a positive impact on workers' health: An overview of systematic reviews. Revista Panamericana de Salud Publica/Pan American Journal of Public Health, 40(5), 332-340.

Harvey, J. N., \& Lawson, V. L. (2009). The importance of health belief models in determining self-care behaviour in diabetes. Diabetic Medicine. https://doi.org/10.1111/j.1464-5491.2008.02628.x

James, D. C. S., Pobee, J. W., Oxidine, D., Brown, L., \& Joshi, G. (2012). Using the Health Belief Model to Develop Culturally Appropriate Weight-Management Materials for African-American Women. Journal of the Academy of Nutrition and Dietetics. https://doi.org/10.1016/j.jand.2012.02.003

Karyadi. (2008). Dampak Penggunaan Pupuk dan Pestisida yang Berlebihan terhadap Kandungan Residu tanah pertanian Bawang Merah di Kecamatan Gemun Kabupaten Kendal. Agromedia, 26(1), 10-19.

Kementerian Kesehatan Republik Indonesia. (2018). Entaskan Kemiskinan Desa, Kementerian Pertanian Canangkan Program Bekerja. Retrieved February 4, 2019, from http://www.depkes.go.id/pdf.php?id=18042300006

Kholid, A. (2015). Promosi Kesehatan: Dengan Pendekatan Teori Perilaku, Media dan Aplikasinya. Jakarta: PT RajaGrafindo Persada.

Khozanah, M. (2010). Pestisida Organoklorin di Perairan Teluk Klabat-Pulai Bangka. Oseanologi Dan Limnologi Di Indonesia, 36(1), 1-19.

Kurniasari, L., Hartati, I., \& Riwayati, I. (2009). Pemberdayaan Masyarakat Petani dengan Penerapan Teknologi Pembuatan Insektisida Nabati dari Limbah Penyulingan Daun Nilam. Momentum, 5(2), 41-45.

Lennon, J. L. (2005). The use of the health belief model in dengue health education. Dengue Bulletin.

Lewis G, H., Sheringham, J., Kalim, K., \& Crayford, T. J. (2014). Mastering public health a postgraduate guide to examinations and revalidation. Boca Raton, USA: Taylor \& Francis Group, LLC. https://doi.org/10.1201/b17699

Lu, F. C. (2006). Toksikologi Dasar (Asas, Organ Sasaran, dan Penilaian Resiko) Edisi Kedua. Jakarta: Universitas Indonesia.

Macfarlane, E., Carey, R., Keegel, T., El-Zaemay, S., \& Fritschi, L. (2013). Dermal exposure associated with occupational end use of pesticides and the role of protective measures. Safety and Health at Work, 4(3), 136-141. https://doi.org/10.1016/j.shaw.2013.07.004

Machfoedz, I., \& dan, S. E. (2006). Pendidikan Kesehatan Bagian Dari Promosi Kesehatan. Yogyakarta: F Tranaya.

Mahyuni, E. L. (2015). Faktor Risiko dalam Penggunaan Pestisida Terhadap Keluhan Kesehatan Pada Petani di Kecamatan Berastagi Kabupaten Karo 2014. Kesmas, 9(1), 79-89.

Mahyuni, E. L., Yustina, I., \& Sudaryati, E. (2017). Safety Talk and Check to Prevent Pesticide Toxicity among Farmer. International Journal of Public Health Science (IJPHS), 6(4), 293-298. https://doi.org/10.11591/ijphs.v6i4.9113

Maulana, H. (2007). Promosi Kesehatan. Jakarta: EGC.

Melzner, J., Heinze, J., \& Fritsch, T. (2014). Mobile Health Applications in Workplace Health Promotion: An Integrated Conceptual Adoption Framework. Procedia Technology. https://doi.org/10.1016/j.protcy.2014.10.155

Minaka, I. D. A., Sawitri, A. A. S., \& Wirawan, D. N. (2016). Hubungan Penggunaan Pestisida dan Alat Pelindung Diri dengan Keluhan Kesehatan pada Petani Hortikultura di Buleleng , Bali Association of Pesticide Use and Personal Protective Equipments with Health Complaints among Horticulture Farmers in Buleleng, Bali. Public Health and Preventive Medicine Archive, 4(1), 94-103. https://doi.org/10.24843/PHPMA.2016.v04.i01.p12

Moekasan, T. K., \& Prabaningrum, L. (2011). Penggunaan Pestisida Berdasarkan Konsepsi Pengendalian Hama Terpadu (PHT). Bandung: Yayasan Bina Tani Sejahtera. 
Munawir, K. (2005). Pemantauan Kadar Pestisida Organoklorin di Beberapa Muara Sungai di Perairan Teluk Jakarta. Oseanol. Limnol. Indonesia, 37, 13-23.

Notoatmodjo, S. (2003). Pendidikan dan Perilaku Kesehatan. Jakarta: Rineka Cipta.

O'Connor, P. J., Martin, B., Weeks, C. S., \& Ong, L. (2014). Factors that influence young people's mental health help-seeking behaviour: A study based on the Health Belief Model. Journal of Advanced Nursing. https://doi.org/10.1111/jan.12423

Onoruoiza, S. I., Musa, A., Umar, B. D., \& Kunle, Y. S. (2015). Using Health Beliefs Model as an Intervention to Non Compliance with Hypertension Information among Hypertensive Patient. International Organization of Scientific Research Journal Of Humanities And Social Science. https://doi.org/10.9790/0837-20951116

Osang, A. R., Lampus, B. S., \& Wuntu, A. D. (2016). Hubungan antara masa kerja dan arah angin dengan kadar kolinesterase darah pada petani padi pengguna pestisida di Desa Pangian Tengah Kecamatan Passi Timur Kabupaten Bolaang Mongondow. PHARMACON, 5(2), 151-157.

Rosenstock, I. M. (1977). The Health Belief Model and Preventive Health Behavior. Health Education \& Behavior. https://doi.org/10.1177/109019817400200405

Rumah Sakit Umum Kabanjahe. (2018). Data Pasien Intoksikasi Periode Januari-Oktober 2017: Rekam Medik Rumah Sakit Umum Kabanjahe Kabupaten Karo. Kabanjahe.

Rustia, H. N., Wispriyono, B., Susanna, D., \& et al. (2010). Lama Pajanan Organofosfat Terhadap Penurunan Aktivitas Enzim Kolinesterasi Dalam Darah Petani Sayuran. Makara Kesehatan, 14(2), 95-101.

Sentra Informasi Keracunan Nasional. (2017). Berita Keracunan Bulan Juli-September 2017. Retrieved April 15, 2018, from http://ik.pom.go.id/v2016/berita-keracunan/berita-keracunan-bulab-juli-september-2017

Setiawan, D. A., Redjeki, E. S., \& Nasution, Z. (2017). Analisis Proses Pembelajaran Dalam Konsep Pemberdayaan Kelompok Tani. Jurnal Pendidikan, 2(8), 1077-1080.

Sharifzadeh, M. S., Damalas, C. A., \& Abdollahzadeh, G. (2017). Perceived usefulness of personal protective equipment in pesticide use predicts farmers' willingness to use it. Science of the Total Environment, 609(31), 517-523. https://doi.org/10.1016/j.scitotenv.2017.07.125

Simonsen-Rehn, N., Laamanen, R., Sundell, J., Brommels, M., \& Suominen, S. (2009). Determinants of health promotion action in primary health care: Comparative study of health and home care personnel in four municipalities in Finland. Scandinavian Journal of Public Health, 37(1), 4-12. https://doi.org/10.1177/1403494808096171

Sinulingga. (2006). Telaah Residu Organoklor pada Wortel (Dacus carota L.) di Kawasan Sentra Kab. Karo Sumut. Jurnal Sistem Teknik Industri, 7(1), 92-97.

Solhi, M., Zadeh, D. S., Seraj, B., \& Zadeh, S. F. (2010). The application of the health belief model in oral health education. Iranian Journal of Public Health.

Strecher, V., \& Rosenstock, I. (1997). The health belief model. Cambridge Handbook of....

Sukmawati, A., \& Maharani IP, A. (2004). Hubungan Antara Perilaku dalam Pengelolaan Pestisida dengan Aktivitas Enzim Cholinesterase Darah pada Petani Cabe di Desa Santana Mekar Kecamatan Cisayong Kabupaten Tasikmalaya. Jurnal Ekologi Kesehatan, 3, 80-89.

Syahyuti. (2016). Relevansi Konsep dan Gerakan Pertanian Keluarga (Family Farming) serta Karakteristiknya di Indonesia. Forum Penelitian Agro Ekonomi, 34(2), 87-101. https://doi.org/10.21082/fae.v34n2.2016.87-101

Thalacker, K. M. (2011). Hypertension and the Hmong Community: Using the Health Belief Model for Health Promotion. Health Promotion Practice. https://doi.org/10.1177/1524839909353735

United Nations Children's Fund (UNICEF). (2018). Understanding the Impact of Pesticides on Children: a disccussion paper. New York, USA: United Nations Children's Fund (UNICEF).

World Health Organization. (2017). World Health Statistics 2017: Monitoring Health for the SDGs, sustainable development goals. Geneva.

Yarpuz-Bozdogan, N. (2018). The importance of personal protective equipment in pesticide applications in agriculture. Current Opinion in Environmental Science \& Health, 4, 1-4. https://doi.org/10.1016/j.coesh.2018.02.001

Yuantari, M. G. C. (2011). Dampak Pestisida Organoklorin Terhadap Kesehatan Manusia dan Lingkungan Serta 
Penanggulangannya. Prosiding Seminar Nasional Peran Kesehatan Masyarakat Dalam Pencapaian MDG'S Di Indonesia, (April), 187-199.

Yuantari, M. G. C., Widianarko, B., \& Sunoko, H. R. (2015). Analisis Risiko Pajanan Pestisida Terhadap Kesehatan Petani. Jurnal Kesehatan $239-245$. https://doi.org/10.15294/kemas.v10i2.3387

\section{Copyrights}

Copyright for this article is retained by the author(s), with first publication rights granted to the journal.

This is an open-access article distributed under the terms and conditions of the Creative Commons Attribution license (http://creativecommons.org/licenses/by/4.0/). 